\begin{abstract}
This paper discusses the key hypotheses which Joseph Stiglitz proposed, in his wide-ranging critique of the 'Washington Consensus', with regard to transition reforms and economic polices in China and Russia. The primary purpose is to evaluate the Stiglitz perspective in the light of empirical evidence, including the experience of countries outside China and Russia. Although some of the points Stiglitz makes are important for understanding what has happened in the transition, this paper argues that his perspective mis-interprets the key facts of the Chinese transition, mis-describes the facts of the Russian transition and fails to consider the theoretical and policy implications of the success of a "third model", which is represented by some Central European and Baltic transitions.
\end{abstract}

This paper was produced as part of the Centre's

Globalisation Programme 


\section{Whence Reform? A Critique of the Stiglitz Perspective}

\section{Marek Dabrowski, Stanislaw Gomulka and Jacek Rostowski}


Published by

Centre for Economic Performance

London School of Economics and Political Science

Houghton Street

London WC2A $2 \mathrm{AE}$

(C) Marek Dabrowski, Stanislaw Gomulka and Jacek Rostowski, submitted March 2000

ISBN 0753014114

Individual copy price: $£ 5$ 


\section{Whence Reform? \\ A Critique of the Stiglitz Perspective}

\section{Marek Dabrowski, Stanislaw Gomulka and Jacek Rostowski}

1. Introduction 1

2. Stiglitz's Key Hypotheses 2

3. Two Key Definitional Issues 4

4. Three Models of Transition from Communism 6

5. Organisational Capital 11

6. Social Capital 12

$\begin{array}{ll}\text { 7. Short Agency Chains and Privatisation } & 14\end{array}$

8. Privatisation, Corruption, Asset Stripping and Capital Flight 16

9. Bankruptcy and Restructuring 17

10. Inequality, Liberalisation and Stabilisation 19

11. Conclusion 21

$\begin{array}{ll}\text { References } & 24\end{array}$ 


\section{Acknowledgements}

Marek Dabrowski is a member of CASE - Centre for Social and Economic Research (Warsaw). Dr Gomulka is a member of CASE; a senior associate of the Centre for Economic Performance, London School of Economics and member of the Department of Economics, LSE. Jacek Rostowski is a member of CASE and of the Central European University, Budapest. 


\title{
Whence Reform? A Critique of the Stiglitz Perspective
}

\author{
Marek Dabrowski, Stanislaw Gomulka \\ and Jacek Rostowski
}

\section{Introduction}

That the transition from communism is largely over can be seen in the fact that the battle over its historical interpretation has begun ${ }^{1}$. An early salvo in this battle has been fired by Joseph Stiglitz (1999a and 1999b), at the time Senior Vice-President of the World Bank, in a blistering attack aimed at both the Washington consensus (of the IMF, World Bank and US Treasury) which, he claims, foisted tragically mistaken policies on the countries emerging from communism, and at unnamed 'western advisers' who misunderstood both the true nature of capitalism and the nature of the reform process. Furthermore, Stiglitz contrasts two models of transition. On the one hand, he says, is China, where institutional reform has been gradual, building on already existing solutions, and economic growth has been rapid. On the other, there is Central Europe (CE) and the former Soviet Union (fSU), above all Russia, where reformers and their western advisers, both institutional and personal, organised a 'blitzkrieg' on existing economic structures, pursuing a 'clean slate' policy by which they tried to "engineer...the new, clean, and pure 'textbook institutions' of a private economy." Some western advisers were just bolsheviks 'a rebours', only "using the right textbooks this time" (or so they believed). The result has been a massive fall in economic activity ${ }^{2}$. This occurred, says Stiglitz, partly because superficial modern economics textbooks informed the thinking of the advisers, rather than the deeper and more subtle Austrian approaches of Hayek and Schumpeter, or more advanced and rigorous modern journal articles of such authors as Stiglitz himself.

We do not feel directly targeted by this criticism, for although we have all been advisers (and one of us has been also a decision maker) during the transition, we are all East European. Moreover, we believe that some of the points Stiglitz makes are important for understanding what has happened in the transition (and indeed what occurred during the development of capitalism in West). This is particularly the case when he points, in the context of corporate governance, to the impossibility of quickly building "long agency chains". However, we shall argue that the picture Stiglitz paints of the transition is fundamentally flawed in three key respects:

1. His misinterpretation of the facts of the Chinese transition

2. His misdescription of the facts of the Russian transition

3. His failure to consider the implications of the success of the "third model", which is represented by some Central European and Baltic transitions (particularly the Estonian, Hungarian and Polish).

\footnotetext{
${ }^{1}$ We speak here of the transition from communism, not of the transition to capitalism. It is clearly not the case that all the post-Communist countries have become, or will inevitably become, normal and successful capitalist market economies. But it is now fairly clear which ones will succeed in achieving this in the foreseeable future and which ones will not, and what kind of system has developed in each.

${ }^{2}$ Probably the largest in peacetime in modern history, as we all agree.
} 
The result of these flaws is a deep misunderstanding of the real choices open to decision makers in Russia at the beginning of the 1990s, and therefore a profound misinterpretation of history. What is more, if this interpretation were to be believed by policymakers in the countries which have lagged behind in transition, it could lead to a continuation of a failure to come to grips with the barriers to economic growth. Setting the record straight will not, of course, change the outcome for Russia, or transform its failure into success. It may, however, persuade future policy makers to reject an imaginary 'participatory' approach to economic reform based on a large dose of communitarian romanticism.

The paper is organised as follows. In the next section we present what we think are Stiglitz's 20 key hypotheses regarding capitalism and the transition to it. In Section 3 we address what is meant by the terms "success of transition" and "privatisation". In Section 4 we challenge Stiglitz's interpretation of the Chinese and Russian models of transition, and describe the Central European (particularly Polish) and Baltic model which he ignores. In the subsequent seven sections we assess his hypotheses (grouped as below in Section 2) in the light of the discussion in Section 4. Finally, we summarise and put forward our own explanation for the failure, to date, of the Russian transition.

\section{Stiglitz's Key Hypotheses}

\section{Organisational Capital}

1. The organisational capital present in enterprises under socialism is still very valuable under conditions of transition. It needs to be preserved rather than destroyed. Once dissipated, this organisational capital is hard to reassemble, particularly in environments with little entrepreneurial experience.

2. Entrepreneurial efforts that arise out of or spin-off from existing enterprises may be particularly effective $e^{3}$.

3. A high rate of new enterprise creation was not to be expected in the fSU given its lack of a history of 'market oriented entrepreneurship'. FSU entrepreneurs, writes Stiglitz, have developed skills in evading and profiting from government regulations, but these are far different from those needed for creating new businesses and competing on international markets.

4. Given the low probability of new enterprise creation and the difficulties in reassembling organisational capital once dissipated, it is particularly important to promote the restructuring of existing state enterprises.

\section{Social Capital}

5. Social capital encompasses the civil norms which allow trust, and this in turn is important for all forms of inter-temporal trade. Such capital is vital to a functioning market economy. Without it, social interaction would be reduced to a minimum of tentative and distrustful commodity sales.

\footnotetext{
${ }^{3}$ Other social organisations that might incubate and support entrepreneurial efforts include local township governments, unions, schools...
} 
6. The social norms which existed under socialism are inadequate for a market economy, yet the development of new norms is bound to be time consuming. Imposing laws which do not correspond to existing norms is likely to fail because they will not be implemented in the right spirit (if at all).

\section{Short Agency Chains and Privatisation}

7. In the more developed market economies long multi-stage chains of agency relationships have developed. If one tries to just set up a market economy overnight with such extended agency relationships, this superstructure may collapse in dysfunction. Long agency chains, such as those implicit in voucher privatisation schemes (where workers are agents for managers, managers for funds and funds for citizens) are likely to generate fraud and inefficiency, contributing to output collapse and impeding subsequent recovery. This is why the method of privatisation matters.

8. In the early transition, therefore, agency chains should be as short as possible. One example of this is the owner-operated business.

9. Another way of establishing short agency chains is to privatise to the various stakeholders in the business (workers, suppliers, customers, representatives of the local community) who have a long-term relationship to the enterprise. This also helps to save the organisational capital within state owned enterprises (SOEs) - Thesis 1 above. Hence the correct sequencing of reform is: regulate up front, restructure next, and privatise only when market institutions are in place.

\section{Privatisation, Corruption, Asset Stripping and Capital Flight}

10. The 'Coasian' hypothesis that it does not matter whom assets are privatised to initially because initial buyers will sell out to the highest bidder, and the highest bidder will be the most efficient potential manager of the assets, is wrong in transition economies. The most efficient potential managers cannot buy the assets because they do not have the wealth.

11. Inefficient new owners will therefore asset strip their companies. Paradoxically, the same would happen if innately efficient managers could borrow to purchase privatised firms. This is because they would be so highly leveraged that they would have a great incentive to strip assets from the firm which they control (1999b) ${ }^{4}$.

12. Inefficient new owners will invest much of their wealth in the political system, so as to obtain preferential access to further state property to asset strip. This leads to the corruption of both the political and economic systems.

13. Privatisation carried out in this way will not be accepted as legitimate by society, so that even if the property rights created in this way are very clearly defined as required by Coase, they will not be secure. This provides a further reason for asset stripping by new owners and capital flight, the latter made easier in Russia by premature capital account liberalisation.

\footnotetext{
${ }^{4}$ One of us, as Supervisory Board member of a Polish state bank, stopped a number of proposed loans of this kind, for this very reason.
} 


\section{Bankruptcy and Restructuring}

14. Bankruptcy is unlikely to result itself in much restructuring. In the West most restructuring takes place before bankruptcy.

15. Pre-bankruptcy restructuring should be fostered by encouraging decentralisation of decisions within SOEs, so that the constituent parts can look for customers and suppliers outside the existing firm and engage in 'horizontal discussions' with other units so as to rebuild organisational relationships 'from the ground up', leading to recombination of the units into new firms.

16. Making workers unemployed, whether through the bankruptcy or even the restructuring of existing firms, is likely to be economically inefficient. While employed they are at least producing something, whereas - because of a lack of 'market-oriented skills' among entrepreneurs - they are unlikely to find employment in new firms. The same holds for the capital made unemployed through bankruptcy.

17. Finally, the wrong firms are likely to be bankrupted since under socialism finance was not allocated on a commercial basis, with the result that the distribution of debt is largely random in the transition, and so is bankruptcy.

\section{Inequality, Liberalisation and Stabilisation ${ }^{5}$.}

18. The rapid transition attempted in the fSU and Eastern Europe has led to increased inequality, increased poverty and reduced life expectancy.

19. Rapid liberalisation did not lead to rapid growth, at least in Eastern Europe.

20. The same is true of stabilisation. Because of the need for relative price adjustments, very rapid stabilisation of reduction may actually hinder micro-economic adjustment.

\section{Two Key Definitional Issues}

For reform evaluations and comparisons, both Stiglitz and ourselves use the terms 'success' and 'privatisation'. These terms may not and need not be precisely defined, but should at least be explained.

In his inter-temporal comparisons of China and Russia, Stiglitz uses the official growth rate of GDP as the yardstick of the success of reforms. This standard measure is appropriate in most normal circumstances, but it is in our view inappropriate, indeed misleading, in the initial period of transition. The reason is that, at that time, economic developments in the fSU and CE reflected not so much the quality of current reforms, but the pre-reform crisis conditions, which led to the collapse of the Soviet style economic, military and political system. In Russia, because of this crisis, industrial output started to fall sharply already in 1991, still under the old system. Whether reform had taken place or not, this fall would have presumably continued as the system unwound, as the experiences of slow and/or

\footnotetext{
${ }^{5}$ All three theses are presented in Stiglitz (1999b). They are initially discussed on p.2. This is a significant departure from Stiglitz (1999a), where stabilisation of inflation is praised and liberalisation is passed over in silence, although the growth in inequality in Russia is, of course, discussed.
} 
late reformers would indicate, eg Bulgaria, Romania and Belarus. For the collapse of the Warsaw Pact (and the associated contraction of the defence industry), of the CMEA (and the associated contraction of trade) and of the USSR itself (and the associated disruption of intraSoviet production links), have all been the inevitable consequences of earlier events, in Russia and elsewhere. The reduction in the output of the defence and related industries alone, according to one knowledgeable source, accounts for 60 percent of the fall in industrial production in Russia (Yasin, 1999). China, on the other hand, was almost completely immune to all these phenomena of disintegration, and thus to the economic disruption they brought in their train. Furthermore, under socialism both output levels and output growth were overstated (as managers tried to fulfil output targets on paper), while in the new market economy they tend to be understated (as businesses try to avoid taxes). ${ }^{6}$

Reforms themselves have involved rapid and massive changes in relative prices, mainly as a result of price and trade liberalisations, sharp increases in nominal (typically also real) interest rates, massive up-front devaluations and harmonisations in turnover tax rates. These changes in relative prices caused shifts in demand and supply functions which, in conditions of probably extremely low mobility of resources and apparently fairly limited wage flexibility, tended to reduce outputs and increase inflation. For these reasons it would have been better if some of the required changes in relative prices had been introduced more gradually, still under the old system, as they have been in China. It was the resistance to such reforms by earlier regimes in CE and, especially, in the fSU which meant that price and structural distortions reached crisis levels. When the crisis came, the old system collapsed swiftly, and this collapse necessitated the establishment very quickly of a market-based coordination mechanism, at the core of which are, of course, free market-clearing prices. Moreover, the other reasons for output falls meant that structural adjustments would have to be swift and large anyway. Rapid price, trade and entry (PTE) liberalisations were thus also needed to facilitate that supply-side restructuring. Finally, the need to enhance competition in markets which were often dominated by a few large firms also called for rapid PTE liberalisations.

We therefore propose to measure success of reform in transition countries by their ability to recreate the (institutional, legal and economic) conditions for rapid and sustainable growth. This ability is indicated by the increase of output from the start of recovery. It is this yardstick which has differentiated the Baltic countries strongly from Russia within the fSU, and much of CE from much of the fSU.

A final point needs to be addressed here. Stiglitz (1999b) states that the closing down of loss-making enterprises cannot be a justification for the fall in output at the start of the transition, since, if the resources previously used in such production are now made idle, their true opportunity cost is zero, and therefore they should have been kept in their old use (where the value added is low, but more than zero). ${ }^{7}$ This is wrong in principle. The purpose of reforms is both to restructure transition economies in favour of activities producing more

\footnotetext{
${ }^{6}$ Stiglitz also compares post- and pre-transition growth for 19 transition countries (Figure 1, 1999b) where he supposedly "compares the average growth rate of the economies in transition for the decade prior to the transition with the past decade" (p.2). Although a number of socialist economies suffered a significant slowdown in the 1980s, Stiglitz gets round this by in fact comparing figures for the years 1977-89 with 198998! Furthermore, although no source is given, Figure 1 is headed "Average GDP Growth". This is surprising, in that none of the countries concerned calculated their GDP in the 1980s. Since it excludes most services, the Net Material Product which they did calculate usually grows noticeably faster than GDP. Stiglitz (1999b) also claims that the widespread use of barter in Russia may give an upward bias to GDP figures in that country during the transition. This may be so, but it does not remove the usual tax avoidance reason for output understatement, or the fact that - more or less - correct transition output is compared by Stiglitz to socialist output which is overstated by a large, but not precisely known, amount.

${ }^{7}$ This is an application of Thesis 16 to the question of growth in the transition.
} 
value added per unit of primary inputs (of labour and capital), and to enable them to respond flexibly in future to changes in supply and demand conditions. Of course, if real wages were perfectly flexible and labour and capital resources were perfectly moveable, then no fall of output would be necessary. However they are not, and unemployment, although it does involve short-term costs both psychological and in terms of output foregone, performs a positive role by making it clear to people that they have to either change skills and move to higher productivity work or accept lower real wages. Therefore, the welfare cost associated with a temporary increase in unemployment and output can be thought of as an investment needed to achieve permanent welfare gains from the better allocation of labour and other resources in the future. ${ }^{8}$

As regards the concept of 'privatisation', we use the standard measure of the share of output which originates in the private sector. This concept refers, thus, to the privatisation of the entire economy, and not necessarily to the privatisation of enterprises. Such economywide privatisation may occur, as it did in China or Poland, through the fast expansion of a new private sector relative to the rest of the economy, rather than through privatisation of existing SOEs.

\section{Three Models of Transition from Communism}

Much of Joseph Stiglitz's argument is based on the contrast between the success of the Chinese transition and the economic failure so far of the Russian. We suggest that Stiglitz has misunderstood the reasons for China's success, and misunderstood the facts (and therefore the causes also) of Russia's failure. Finally, he has ignored the success of some of the Central European and Baltic countries, and therefore has misconceived the real requirements for successful transition.

A key reason for China's success was indeed its underdevelopment. The first way this has helped has been the fact that only one fifth of the workforce was employed in the state sector at the start of the reforms in 1978. It was therefore possible to build a whole new industrial sector from scratch, taking advantage of the underemployed labour which existed in the countryside, without having to restructure the existing SOEs. This new sector consists of so-called Township and Village Enterprises (TVEs) and new private firms. Just like the creation of the de novo private sector in Poland and Estonia, this proved faster, easier and more efficient than trying to restructure the economy by restructuring the state firms. The bulk of the growth in China has come from these new non-state enterprises that operate freely on the market (see Xu and Zhuang, 1999, and Woo, 1998).

Nevertheless, it is the case that the production of SOEs has continued to expand in China since 1978. This is related to the second feature of China's underdevelopment: its low productivity and the opportunities which exist as a result for rapid catching-up. This is known as the "Gerschenkron phenomenon" of the "relative advantages of backwardness". In this respect the China of the 1980s and 1990s was like Russia from the 1930s through to the 1960s, when her own SOEs were very successful in expanding output and increasing productivity according to official statistics (Gomulka, 1977, 1986 and 1988b). Stiglitz just chooses to ignore the impact of this significant difference in the level of development on performance.

Of course, China had to create the framework in which new firms could be established and grow, and this has been an important achievement. However, it needs to be

\footnotetext{
${ }^{8}$ China did not need to generate unemployment of this kind during its reforms due to the abundance of underemployed labour it had in the countryside (see next section).
} 
remembered that the absence of privatisation and of an 'institutional big bang' has not inhibited the growth of corruption in China, which seems to be on a scale comparable to that in Russia (Section 6). The same may be true of asset stripping and the amount of capital flight from China (Section 8).

Furthermore, in spite of the impression given by Stiglitz, it does not seem to us that corporate governance is particularly well developed in China. Although "agency chains" are indeed short, this is mainly because it is unclear whose agents the local authorities that appoint 'township and village enterprise' managers really are: the provincial government's, the Communist Party's? They certainly are not the agents of the local population, as they are unelected. Indeed, it is unclear whether they are anybody's agents. Rather, managers and township officials form a local elite which rules in its own interests. Thus 'agency chains' in China may not so much be short as non-existent! Finally, China has also failed to conform to Stiglitz's prescriptions by maintaining a high level of unemployment throughout its transition.

Thus we reject the idea that China's economic transition has been successful because it:

1. Achieved efficiency enhancing restructuring by conserving the organisational capital of its SOEs.

2. Sustained useful social norms inherited from socialism and avoided corruption thanks to gradual institutional development.

3. Avoided harmful types of asset stripping by privatising to stakeholders and maintaining 'short agency chains'. On the other hand it is true that China has had little recourse to bankruptcy of SOEs, but with such huge underemployment of the rural labour force and the small size of the state sector, it did not need to.

As regards Russia, Joseph Stiglitz makes three important factual errors and, we suggest, one fundamental error of interpretation. The first error is the statement that manufacturing industry was privatised to outside 'oligarchs' and the attendant belief that had it been privatised to inside 'stakeholders', the Russian economy would have fared better. Stakeholders would have restructured the firms, preserving their organisational capital, rather than asset stripping them, and the oligarchs would not have been able to develop their noxious power, based on a combination of finance and political influence. In fact, some 70 percent of manufacturing firms was initially privatised through Variant II of the mass privatisation scheme to workers and managers, who are the classical stakeholders ${ }^{9}$. The subsequent evolution of the ownership structure in the direction of outsider control was the result of free choices made by the insiders to sell out, and was in any case very modest (Frydman, Pistor, Rapaczynski and Turkewitz, 1996). Thus restructuring failed in Russia in spite of the very privatisation to stakeholders that Stiglitz recommends. Second, the oligarchs made their money not through asset stripping manufacturing firms, but through their preferential access to cheap credits from the Central Bank of Russia, the preferential privatisation to them of natural resource based (not manufacturing) firms, and their ability to arbitrage the difference between controlled domestic natural resource prices and free world market ones. They were also helped by the policy of closing off the Russian financial sector to foreign competition. Finally, a premature lifting of capital controls did not contribute to asset stripping, as Stiglitz claims, for the simple reason that capital controls were never

\footnotetext{
${ }^{9}$ The last variant, Variant III, was also insider dominated.
} 
lifted $!^{10}$

These facts undermine Stiglitz's main point about the Russian transition: that in their haste the Russian reformers followed the wrong privatisation strategy, excluding stakeholders, with disastrous results in terms of restructuring, asset stripping and growth. His second point, that this same mistake led to the massive corruption of the political system, is also wrong. It was in fact the other way round: an immature and corrupt political system has led to inefficient and politically motivated privatisations of the natural resource sectors.

Stiglitz also claims that failure to privatise to insiders was part of a wider desire to destroy existing institutions and norms, which were perceived by the reformers as tainted by communism. This created a moral void, which has led to the flowering of crime and corruption. We have pointed out above that mass privatisation in Russia did not in fact destroy existing stakeholder groups or organisational capital. Instead, crime and corruption were probably more affected by the limited nature of price and trade liberalisation in Russia, a process which was carried out far more thoroughly in CE and the Baltics, where it did not lead to a similar collapse of norms ${ }^{11}$ (Section 6). Furthermore, we believe that many of the old social norms relating to economic activity, which had existed under socialism, died before the collapse of communism. Indeed, their death was a major reason for its collapse. This is the major difference in interpretation regarding Russia between us and Stiglitz. Thus, in our view, in many areas there were no existing norms at all for the reformers to build new institutions upon. Some new institutions therefore had to be created quickly in the hope that new norms would follow, because the old institutions could not function as the social norms that had under-pinned them no longer existed ${ }^{12}$.

Finally, Stiglitz largely ignores the successful transitions of CE and the Baltics. One of the more successful countries has been Poland, where at the time of writing (2000) real GDP was one quarter higher than at the beginning of the transition in 1989, by far the best result in the region. After a short but sharp contraction of about 15 percent in 1990 and 1991, the economy has grown at an average rate of 5 percent per annum, compared to almost zero growth during the 1980s, the last decade of socialism. Estonia, Latvia, Lithuania, Hungary and Slovenia have also experienced rapid growth in the last few years. What enabled Poland, which has had the best and most consistent growth record in CE, to achieve such success in the 1990s after its failures in the 1980s?

The Polish model of transition consisted of five main elements:

1. Complete liberalisation of de novo private sector entry into almost all areas of economic activity (January 1989).

2. Abolition of communist party organisations in SOEs, which gave real power to the workers' councils that had formally exercised it since 1981(end 1989).

3. Very rapid price liberalisation (during 1989 the share of freely determined prices

\footnotetext{
${ }^{10}$ Capital flight in Russia has happened in spite of capital controls. The Central Bank of Russia has described some of the methods used (Financial Times, February 6, 2000).

${ }^{11}$ However, this thoroughgoing liberalisation of prices and trade probably did much more to destroy existing entrenched interests than did the mass privatisation so reviled by Stiglitz. Thus home grown gradualists and opponents of reform in Eastern Europe often opposed 'shock price, trade and entry liberalisation' as much, if not more than, 'shock privatisation'. We suspect that they understood the process better than does Stiglitz.

${ }^{12}$ In early 1992 two of us, who were acting as advisers to the Russian government at the time, reproached Yegor Gaidar (at the time the Deputy Prime Minister in charge of the economy) with the maintenance of goszakazy (obligatory state delivery orders) on a large proportion of the output of the oil industry. This was in fact 'dual pricing' of the Chinese kind, so praised by some gradualists ( $\mathrm{g}$ McKinnon, 1991). Gaidar's response was that these orders would be ignored by producers anyway.
} 
rose from 25 percent to 90 percent) ${ }^{13}$.

4. Introduction of hard budget constraints on SOEs and stabilisation of inflation through tight fiscal, monetary and wages policies (January 1990).

5. Current account convertibility of the currency and almost complete foreign trade liberalisation (January 1990).

This was certainly the most rapid programme of market reforms that had been implemented until that time, although it should be noted that until 1995 privatisation of SOEs was not very rapid and was largely limited to small and medium sized firms. The results of the programme were:

1. The rapid introduction of market prices based on relative scarcity and world prices for traded goods.

2. A financial squeeze on SOEs, which forced them to quickly release excess labour and physical capital (so called asset privatisation) ${ }^{14}$.

3. The maintenance of a minimum tolerable level of effective corporate governance in SOEs thanks to the workers' councils.

4. Very rapid development of the de novo private sector. ${ }^{15}$

As we noted earlier, growth resumed quickly (in the third year of the transformation, compared to the Russian case where it has taken 8 years) and has proceeded at a rapid pace ${ }^{16}$. In the early transition growth was driven entirely by de novo private sector development, rather than through the restructuring of SOEs, privatised or otherwise (Rostowski, 1993, Gomulka, 1998a,b). De novo private activity, which at first grew rapidly in services, began to expand in manufacturing industry at a rate in excess of 40 percent per annum already in 1991. An average rate of growth in excess of 25 percent was then sustained for about 5 years. More recently foreign direct investment has begun to make a significant contribution to growth. All this has resulted in a doubling of manufacturing output since $1991^{17}$.

This Polish experience (and to an extent that of other Central European and Baltic countries) demonstrates:

\footnotetext{
${ }^{13}$ We include the final liberalisation of some 30 percent of prices on January 1, 1990 in this figure. Detailed descriptions of the programme and the model are contained in Lipton and Sachs (1990) Gomulka (1995, 1998a) and Dabrowski (1999).

${ }^{14}$ Unemployment grew very fast, from zero at the beginning of 1990 to 7.5 percent of the labour force at its end.

${ }^{15}$ The experience of Hungary was quite similar. The same five main elements of reform were introduced as in Poland, although this took between two and three years instead of just over one year, and workers councils had little importance. Also, the domestic de novo private sector tended to grow in services rather than in manufacturing, where quite rapid development was due to foreign direct investment. This somewhat more gradual approach led to a fall in GDP at the beginning of the transition, which was slightly deeper than that in Poland (18 percentage points instead of 15). A larger external debt burden and poorer macroeconomic policies meant that stabilisation of the GDP contraction took two years longer than in Poland, but more importantly, the beginning of rapid growth was delayed by five years, until 1997 (De Broek and Koen, 2000).

${ }^{16}$ Unemployment is now about 12 percent, inflation is under 10 percent, the share of industry in GDP is close to western levels at 25 percent compared to over 45 percent at the end of the 1980s.

${ }^{17}$ We start counting at this date because much of the industrial output before 1990 was highly inefficient and only demanded because of the generalised excess demand in the economy and massive protectionist barriers. It was this output which was eliminated in the 35 percent collapse in industrial output of 1990-91.
} 
1. The usefulness of pre-existing rules and institutions as Stiglitz stresses (workers' councils, a commercial code, about one tenth of the labour force in the nonagricultural private sector before the transition).

2. The importance of macro-economic stabilisation and the accompanying imposition of hard budget constraints, which Stiglitz questions.

3. The importance of the liberalisation of prices, trade and entry, which Stiglitz challenges.

4. The possibility of rapid growth of new private enterprise, which Stiglitz flatly denies.

Strikingly, Table 1 (Blanchflower and Oswald, 2000) shows that today one cannot distinguish between ex-socialist and mature western market economies on the basis of the willingness of their populations to undertake self-employment. However, there apparently remains to this day a wide variation between different transition countries in this respect (as indeed there is between different mature western market economies):

\section{Table 1}

Latent Entrepreneurship: An International League Table

Suppose you were working and could choose between different kinds of jobs. Which would you prefer: being an employee or being self-employed?

\begin{tabular}{l|cr}
\hline & $\begin{array}{c}\text { \% who would prefer } \\
\text { to be self-employed }\end{array}$ & $\mathrm{N}$ \\
\hline Poland & 79.9 & 922 \\
Portugal & 73.3 & 1616 \\
USA & 70.8 & 1071 \\
Switzerland & 64.5 & 2216 \\
New Zealand & 64.2 & 1046 \\
W Germany & 64.0 & 957 \\
Italy & 63.3 & 973 \\
Slovenia & 57.8 & 820 \\
Canada & 57.5 & 857 \\
East Germany & 56.6 & 389 \\
Bulgaria & 55.4 & 900 \\
Hungary & 49.8 & 1419 \\
Israel & 49.7 & 972 \\
Great Britain & 45.1 & 953 \\
France & 41.8 & 918 \\
Japan & 40.9 & 1065 \\
Spain & 38.9 & 1138 \\
Sweden & 38.8 & 1129 \\
Czech Rep & 36.8 & 961 \\
Netherlands & 36.0 & 2013 \\
Russia & 33.2 & 1409 \\
Denmark & 29.7 & 992 \\
Norway & 26.9 & 2021 \\
\hline
\end{tabular}

$\mathrm{N}$ is the number of people interviewed in each nation. A sample of the whole adult population is interviewed.

The Israel sample is for Israeli Jews only. Data for Cyprus, Bangladesh and Philippines are omitted. Source: 1997/8 ISSP Module on Work Orientations/ US General Social Survey. 
Thus, "latent entrepreneurship" is high in North America and most of Western and CE (above all Poland), and low in Scandinavia and Russia (and also the Czech Republic). This index presumably expresses not only any cultural predisposition to entrepreneurship which may exist, but also the assessment by the population of the conditions for self-employment (relative to employment) in the country concerned. Thus, the low scores in Scandinavia are possibly due to the high benefits accruing to employees there. Since that is clearly not the case in Russia, we need to consider what reasons might be causing Russians' unwillingness to become self-employed.

In spite of large differences in industrial structure and history between CE and Russia, the differences between Russia and China are much greater, particularly as regards level of development at the beginning of the transition. Comparing Russia with Poland and Estonia in particular, and $\mathrm{CE}$ and the Baltics in general, is likely to be at least as fruitful as comparing it to China. In examining Stiglitz's 20 theses (arranged in six main groups) we therefore draw on all three experiences.

\section{Organisational Capital}

Although they are discussed separately in (1999a), Stiglitz treats organisational and social capital as indistinguishable from reputational capital in (1999b, pp.20-21). We prefer to deal separately with each in the three sections below. Organisational capital we take to be the value of a productive organisation over and above the value of its assets. It exists because things can be done more efficiently within the organisation, due to habits, formal rules and trust which have built up. Organisational capital is thus a name we give to the efficiencies which Coase (1937) used to explain the existence of firms. It can, of course, differ in amount between organisations, even those in the same line of business. We define reputational capital as generating trust between organisations and between organisations and individuals. Within an organisation, we take reputational capital to generate trust which adheres to an individual, whereas if the trust adheres to a post (rather than its holder) then we may be talking of organisational rather than reputational capital. Social capital we take to be far more diffused within a society. On the one hand it consists in formal rules and institutions (legal codes, court systems), on the other in general rules of behaviour, which we expect even from those whose reputation we do not know. For example, in most countries, when asking for directions in a strange city we do not expect to be intentionally lied to.

Our view is that Stiglitz is wrong on both counts in Thesis 1: the organisational capital present in socialist SOEs is not very valuable, and it is not particularly hard to reassemble it in a more efficient way in new private enterprises. The evidence for the former proposition is the fact that, in transition economies, de novo private firms have been found to be far more efficient than all other categories of firm - both privatised and state owned - with the exception of firms run by foreign direct investors (see the large survey-based literature, including Estrin and Wright, 1999; Schaffer et.al, 1998). The reasons for this seem to be the following:

1. Much of the organisational structure of the SOE is unsuited to operation in a market - $e g$ the almost complete absence of a sales and marketing function and the considerable attention paid by management to purchasing (quite rational in a shortage economy) and lobbying the state (rational in a state run economy).

2. The capital structure and the labour skills structure of SOEs are usually unsuited to producing goods profitably at the relative prices which obtain after the 
liberalisation of prices, entry and international trade. Yet 'whittling down' SOEs to the activities which might be efficient is a far harder job than creating new tailor made private firms out of selected physical assets bought from various SOEs or imported from abroad, and labour with particular skills. The reason for this is the resistance of stakeholders to restructuring, compared to the free hand which new entrepreneurs have in deciding what goods to produce, what assets to buy and what labour to hire on competitive markets.

The relative ease of reassembling factors of production (including organisational capital) if the environment is right for new firm creation is demonstrated by the extraordinarily rapid growth in the number, size and output of new private firms in Poland since 1990, which we described in the previous section ${ }^{18}$.

While it is true that fSU entrepreneurs developed skills in evading and profiting from government regulations before the transition, and that many operated on the interface between legal and illegal activity, the same was true of Polish and Estonian entrepreneurs. This is illustrated by the figures for 'economic crime' in Poland, which show a dramatic fall when the transition began, government intervention in the economy was reduced and many commercial activities were decriminalised. The result was that the number of such 'economic crimes' fell from 26,741 in 1985 to 6,042 in 1990. These facts throw doubt on Stiglitz's Thesis 3. The relevant question is therefore not: how could Russian reformers, and their Western advisers, have been so naive as to think that entrepreneurs would create a host of new firms to restructure the economy? but rather: what were the conditions which allowed entrepreneurs to do so in Poland or Estonia but not in Russia? We shall return to this question in the Conclusion.

\section{Social Capital}

We agree entirely with Stiglitz on Thesis 5, and also largely on Thesis 6. Indeed, we suspect that Thesis 6 may have been one of the factors which explains why rapid de novo private sector development occurred in Poland and other Central European and Baltic countries, but not in Russia ${ }^{19}$. Of course, ex ante policy makers had no reason to suppose that this would prove to be the case, as we have argued in the previous section. Our main problem, however, is with the unstated hypothesis that there existed social norms in the Soviet Union which would have allowed the maintenance of the existing structure of industry and the existing level of output for a considerable time. During this time, Stiglitz assumes, new norms could have been developed which would have provided the basis for the new institutions of an efficient form of capitalism. As stated earlier, our understanding is, rather, that the social norms which sustained the communist economic system died or decayed before the system itself collapsed. We can see this, in the case of Poland, in the increase in the number of 'economic crimes' which occurred during the period when belief in the socialist system collapsed between 1980 and $1985^{20}$. In 1980 there were 7,659 such crimes reported, but by 1985 the number had increased to 26,741 .

\footnotetext{
${ }^{18}$ This disposes of Stiglitz's Thesis 4. Furthermore, there is no evidence that any significant number of these firms were spin-offs from SOEs, which casts doubt on Thesis 2.

${ }^{19}$ There were other, more important, reasons which we discuss in the Conclusion. These, we believe were the result of policy errors.

${ }^{20}$ In 1980 the Gdansk shipyard workers went on strike under the slogan "workers of all factories unite!" and in Szczecin the slogan was "Socialism, yes! Deformations (of socialism), no!". By 1985 opinion polls in Poland showed a large majority in favour of a far-reaching shift to a market economy and significant privatisation.
} 
Thus, governments were faced not so much with the task of transforming existing socialistic norms into new capitalist ones, but rather with a state of anomie, or of an absence of norms relevant to economic activity ${ }^{21}$. Clearly, under these circumstances, waiting for the new norms to develop spontaneously before introducing new laws was not a practical option. New laws and institutions had to be introduced quickly in the hope that they would help society to develop the new norms it needed. To this extent the reformers were indeed Bolshevik in their behaviour, but this was out of necessity not inclination (many had been keen readers of Hayek). In some countries this approach succeeded, in others it did not. But there was no way of knowing in advance which countries would prove successful in this respect. Indeed, many observers at the time expected Poland to be in the unsuccessful camp.

Of course, there have been a few backward or very isolated countries where the old socialistic norms continued to hold sway for a long time, Belarus and Turkmenistan being examples. But, being pre-transitional economies and societies, these cases do not appear relevant to a discussion on the optimal path of transition. China certainly does not seem to be the exception which proves (ie tests) the rule. In China, corruption (which we take to be a measure of the degree to which norms are not suited to the needs of a market economy), seems to be on a scale second only to that in the Commonwealth of Independent States (CIS), and ahead of $\mathrm{CE}$ and the Baltics which experienced far more institutional shock therapy.

Table 2

\section{Corruption Perception Indexes (1999)}

(lower score means more corruption)

\begin{tabular}{ll|ll|ll}
\hline Slovenia & 6.0 & Latvia & 3.4 & Russia & 2.4 \\
Estonia & 5.7 & China & 3.4 & Albania & 2.3 \\
Hungary & 5.2 & Belarus & 3.4 & Kazakhstan & 2.3 \\
Czech Rep & 4.6 & Bulgaria & 3.3 & Kyrgyz Rep & 2.2 \\
Poland & 4.2 & Romania & 3.3 & Yugoslavia & 2.2 \\
Lithuania & 3.8 & Ukraine & 2.6 & Uzbekistan & 1.8 \\
Slovakia & 3.7 & Vietnam & 2.6 & & \\
\hline
\end{tabular}

Source: Transparency International reported in Transition Newsletter, October 1999.

Social capital should be thought of as including not only unwritten norms and trust but also laws and formal institutions. In this respect Poland and Hungary were relatively well placed. Poland had a commercial code, which had been in operation since 1982, while Hungary built up a body of company law from $1985 .{ }^{22}$ Furthermore, Poland had a demonopolised commercial property structure (including a large private sector), which only needed the abolition of rent controls for a fairly competitive commercial property market to spring into existence. Hungary had introduced a western style tax system before 1989 and had broken up its monobank into a two tier banking system already in 1987. On the other hand, a number of significant institutional changes were also carried out in the USSR before the transition began. Co-operatives (which were in effect private businesses) were allowed from 1988, and had expanded enormously by 1992. The banking system was thoroughly demonopolised in 1989. As Stiglitz mentions, work collectives received considerable formal powers, and by the beginning of 1992 some 10,000 enterprises had been leased by managers

\footnotetext{
${ }^{21}$ Interestingly, civil norms relevant to family life and inter-personal relations do not seem to have been affected to the same extent initially. Thus crimes of violence and crimes against the family were the same in 1990 as in 1980 in Poland (although subsequently, over the first five years of the transition, they doubled).

${ }^{22}$ This was, in fact, the 1934 code, which was merely suspended by the Communists after the Second World War.
} 
and workers from the state.

We cannot, therefore, explain all of the relative success of transition in CE and the Baltics by the fact that significant reforms preceded the beginning of transition there, but not in Russia. This is especially so since the Baltic countries started with the same institutional inheritance as Russia did, and there were practically no pre-transition reforms in the former Czechoslovakia, which in spite of all its problems, has far outperformed Russia. Thus, the relevant question is: why did 'shock therapy' succeed in building on earlier reforms in Poland and Estonia, while attempted shock therapy failed to do so in Russia?

\section{Short Agency Chains and Privatisation}

We agree very strongly with Theses 7 and 8, and partly with Thesis 9. Indeed, we consider that here Stiglitz has provided an important insight into both the development of capitalism in the West and the transition process in central and eastern Europe. The rapid growth of owner-operated businesses has been the hallmark of those Central European and Baltic transitions which have been successful. We also consider that workers' self-management played an important part in limiting the fall in output and the amount of criminal asset stripping in the state sector in Poland. Indeed, two of us argued at the time in favour of the advantages of workers' management as a form of corporate governance, against the advice coming from the World Bank ${ }^{23}$. Thus we also agree with Stiglitz that the method of privatisation matters, and that methods involving long agency chains (such as the Czech variant of voucher privatisation) are not likely to be very successful for the reasons of breach of trust which Stiglitz describes ${ }^{24}$.

Indeed, we would suggest that there is a very good reason why long agency chains require a long time to develop. This is the need for providers of agency services to build up the 'reputational capital' which will induce the potential purchasers of these services to trust them. Typically, providers of monitoring and screening services come to markets with a certain amount of net worth in the form of physical and financial assets, which stand as guarantee (ie implicit collateral) for the implicit liabilities which they undertake in the process of monitoring and screening. Given a reasonably well functioning legal system, breaches of trust will lead to a loss of physical and financial assets. As providers of agency services build up reputational capital, their need for physical and financial capital to reassure customers declines. As a result, their capital costs fall and they obtain a higher return on equity $^{25}$. This causes a virtuous circle, as such cost savings on capital further increase the value of the reputational capital of the firm, which customers know would be lost in the event of a breach of trust. This is why even in mature capitalist economies, new forms of agency services are often provided by firms which are already well established as providers of other

\footnotetext{
${ }^{23}$ In 1990, Dabrowski was Deputy Minister of Finance and Rostowski was an adviser. The World Bank missions negotiating the Structural Adjustment Loan were eager to see workers' councils replaced by government appointed supervisory boards in SOEs. The World Bank argument was that the state, being the owner of the firms, must manage them. The Polish negotiating team presented the view that, if the state was capable of managing firms effectively, then central planning would have worked. The main rationale for this position was that the workers had better motivation than bureaucrats in ensuring efficient work by their managers. The World Bank representatives were surprised to find themselves accused of 'statism' by the Polish side, and retorted that they were usually accused of being free market ideologues. This shows that the real situation was more nuanced than Stiglitz's picture of 'western' advisers and institutions imposing radical market solutions on unwilling or uncomprehending easterners.

${ }^{24}$ Except for Dabrowski, we supported voucher privatisation at the time, wrongly as it turned out.

${ }^{25}$ By definition, 'reputational capital' cannot be easily borrowed or lent. It does not therefore involve much opportunity cost compared to financial or physical capital.
} 
services which require them to have a large amount of 'reputational capital' ${ }^{26}$. In the early transition, of course, hardly anyone has any reputational capital to $l o \mathrm{e}^{27}$.

Turning to Thesis 9, we have already expressed our view that giving corporate governance rights to workers can be quite efficient in the early transition. However, we have to enter three important caveats. First, workers' management is no different from other forms of agency arrangement, in that it requires some pre-existing tradition (social norms) and reputational capital, which will allow it to function. Representatives elected to the workers' council need to feel obliged to defend the interests of their electors, and not to just further their own. This is particularly important in a context in which privatisation is expected quite quickly, and with it the disappearance of the workers' council, so that representatives may not have the incentive of prospective re-election. In Poland this tradition existed ${ }^{28}$, in Russia it did not. Russian reformers could no more create such a tradition $a b$ ovo than they could have implanted Quaker business ethics in the new capitalist class. This point is confirmed by the fact that, as we pointed out in Section 3, most SOEs in Russia were privatised via Variant II of the voucher privatisation scheme predominantly to the workers. Yet these workers generally proved unable to ensure effective corporate governance for their firms, or to prevent the asset stripping which Stiglitz so deplores.

Our second caveat relates to the inclusiveness of Stiglitz's proposal to privatise to 'the various stakeholders in the business'. He subsequently goes on to identify workers, suppliers, customers and representatives of the local community as the relevant stakeholders. We suspect that such an approach would lead to paralysis and endless conflict between the various entrenched interests within the firm. A vital part of transition is switching suppliers from traditional to new, more efficient, often foreign ones. Equally, sales often need to be shifted to new customers who are prepared to pay more. Entrenching the position of existing interest groups within the decision making structure of the firm would thus be a recipe for failure to restructure, and therefore for failure of the transition. While agency chains should be short, the corporate governance structure needs to be clear, with power concentrated in the hands of those whose interests are most closely aligned with an efficient use of the capital embodied in the firm. This may, under certain circumstances be the local community (Wiles, 1977), or as in Poland the workforce (in spite of the well-known drawbacks of workers' management as compared to mature capitalism) ${ }^{29}$.

\footnotetext{
${ }^{26}$ Take the famous example of 17th century goldsmiths who became bankers in England. This was not just because they had strong-rooms where gold could be deposited safely, but also because they had proved themselves to be trusted with other people's gold when they worked it (and would thus lose not only their new business but also the old, if they failed in their trust). The expansion of banks into mutual fund management in the 1970s follows the same principle.

${ }^{27}$ The difficulties created by this situation were reflected by the debate which took place in Poland in mid-1991 about how to ensure minimally decent corporate governance for the 1000 large SOEs in which the government wanted to abolish workers' management and take into direct state ownership. This was motivated by the disadvantages of workers management mentioned in Footnote 30, despite the misgivings mentioned in Footnote 24. A major difficulty with the proposal was where to find the several thousand supervisory board members which the scheme would require. Private businessmen, although they existed in large numbers, would suffer from a conflict of interests as would politicians and commercial lawyers, bureaucrats would have a lack of motivation, schoolteachers, it was thought, were despised by the population for having been a pillar of the communist regime, doctors were considered to be profoundly corrupt, so the only groups which met the requirements were economists and priests! But priests would not be allowed to participate by the Church hierarchy, and there were not enough economists. This shortage of individuals with the requisite reputation for honesty and relevant competence was, we believe, a major reason why the programme was sharply scaled down and delayed by a number of years.

${ }^{28}$ The first workers' councils were established in Poland during the post-Stalinist thaw of 1956.

${ }^{29}$ These are (1) the tendency to 'underemploy'; (2) to disinvest; (3) to choose technologies which are excessively capital intensive for such investment as does take place. However, we consider that the tendency to disinvest can be beneficial during the transition if it means that physical assets are sold on the open market to
} 
Finally, since we do not think that socialist SOEs had much organisational capital of value, we do not consider it important to 'save' it in its pre-transition form by entrenching the rights of the various stakeholders. Stiglitz's proposal for 'government by discussion' between the various stakeholder groups within firms thus seems to us a striking example of the 'communitarian romanticism', which pervades much recent writing on the importance of social and organisational capital in the transition (eg Gray, 1995).

\section{Privatisation, Corruption, Asset Stripping and Capital Flight}

There are aspects of Theses 10-13 with which we agree, and aspects with which we strongly disagree. Clearly, it matters whom assets are privatised to initially, if only because the reallocation of assets in the market takes place in time, and not instantaneously. The question posed by Thesis 10 is therefore: do assets reach efficient owners faster by being privatised to the population as a whole, to the friends of top politicians, by being kept longer in state hands and then being privatised to more efficient owners (such as foreign investors), or by being privatised rapidly to 'stakeholders' as Stiglitz suggests?

In the previous section, we accepted that "voucher privatisation" has not been efficient, largely for the reasons Stiglitz expounds. We also agree with his (1999b) view that sale to foreigners cannot be a widely applied solution in the early transition. Others have made the point that state ownership does not prevent asset stripping when the state is weak and, above all, when there are many price and trade controls (Aaslund, 1999). We have already expressed our doubts regarding 'multi-stakeholder' privatisation, and pointed out that privatisation to managers and workers (the classical stakeholders) is largely what actually happened in Russia, so that the barrier to the transfer of assets to more efficient users must have lain elsewhere.

An important question is: to what phenomena can the term 'asset stripping' legitimately be applied in transition? In the West, the term is usually applied to so-called 'corporate raiders', who seize management control of a company and sell its most easily realisable assets for prices which together are higher than they paid for the firm, but are said by objectors to be less than the 'true' value the firm would be worth (ie could be sold for) if the raiders were willing to spend time on its restructuring and resuscitation. Implicit in the concept is the idea, so dear to Stiglitz, that there exists in the firm organisational capital which is somehow undervalued by the market for corporate ownership. However, although the old organisational capital might be lost, the Polish, Estonian and Hungarian experiences suggest that the new organisational capital, which is created in its place, might be more valuable.

The biggest weakness of Stiglitz's perspective on this topic is the link he makes between privatisation as it was carried out in Russia, corruption, and the lack of restructuring due to bad corporate governance and asset stripping (Theses 12 and 13). The greatest fortunes in Russia were made not through privatisation of manufacturing (where the restructuring was most needed), but through privatisation of the seignorage stream generated by the Central Bank of Russia (Dabrowski and Rostowski, 1998, Boone and Hoerder, 1998), through arbitraging the differences between controlled prices for raw materials within Russia and free market prices abroad (Aaslund, 1999), and through favouritism in the privatisation of natural resource based industries, which began in 1995. It was the Russian treasury which was directly asset stripped, not the manufacturing firms, and it was the fortunes made at that

those who are able to make better use of them, usually to de novo private firms. Wiles (1977), Chapters 4 and 6 are an early analysis of 'community firms' and their virtues. 
time which have sustained the political power of the oligarchs.

We have already pointed out in Section 4 that capital flight from Russia has not, as Stiglitz claims, occurred as a result of premature liberalisation of capital movements, but in spite of the absence of such liberalisation. This is a mistake that Stiglitz extends in (1999b, p.14) to most transition economies except, strangely, to China, where in fact it appears to be of similar magnitude, relative to exports, as in Russia ${ }^{30}$. The presence of such large capital flight in China suggests that it is paying a price for the lack of clarity in its property rights and corporate governance structures, and for the very reasons that Stiglitz describes with regard to Russia.

Nevertheless, Stiglitz does bring home the point that those of us who thought that rapid privatisation was needed to prevent asset stripping were probably excessively anxious about a phenomenon which, in the light of experience, seems to have been unavoidable and not necessarily undesirable.

Indeed, an important question is: why did asset stripping of the typical Western kind, and indeed of the kind carried out perfectly legally by Polish worker managed manufacturing firms (ie sale of assets for which outsiders have better use), not in fact happen in Russia? If it had, then the dynamic private sector development which so benefited Polish manufacturing, and which was largely absent in Russia, might have occurred. We shall return to this question in the Conclusion.

\section{Bankruptcy and Restructuring}

We agree with Thesis 14 . We would point out, however, that a mechanism for the seizure of assets by creditors is very important both for developing the credit market by encouraging lenders to lend (among other things for restructuring), and for imposing discipline on borrowers. Furthermore, much restructuring does indeed occur before bankruptcy, but this is because the parties know that bankruptcy exists. While decentralising decision-making in SOEs, so that the constituent parts of the firm can recombine into new firms (Thesis 15) is probably harmless, we know of no successful application of this approach. In Poland, at the beginning of the transition constituent plants of multi-plant SOEs were given the right to secede, and hundreds of them did so during 1989-91. Although this was healthy for the economy, it may have looked a lot like asset stripping to the workers left behind in the less profitable plants of a multi-plant SOE! Also, we know of no cases of "recombination" of such "secessionist" plants. ${ }^{31}$.

While Thesis 16 is true in the short run everywhere, if its logic were accepted very

\footnotetext{
${ }^{30}$ If we add the current account surplus and foreign direct investment inflows for the years 1995-98 for China, and then subtract the increase in reserves, we are left with some $\$ 120$ billion unaccounted for. Most of this is capital flight, shown in the IMF's International Financial Statistics (1999) as purchases abroad of investment assets by "other sectors" ( $\$ 50$ billion) and "net errors and omissions" ( $\$ 49$ billion), giving average annual capital flight of about $\$ 33$ billion. When we normalise on the value of exports (which is about twice as high in China), this is quite comparable with Russia, where capital flight has varied between $\$ 12$ billion and $\$ 24$ billion per annum (statement by representatives of the Central Bank of Russia quoted in the Financial Times (5 February 2000, p.2). The Central European countries, on the other hand, have experienced quite large capital inflows during 1995-98 (EBRD, 1999).

${ }^{31}$ Poland developed a fairly competitive structure of state industry early in the transition. In the second half of the 1980s, before the beginning of the transition proper, the giant associations of enterprises (zrzeszenia) that existed under central planning were abolished. Then, at the start of the transition, whole sectors were demonopolised "from above" by the government (meat processing, sugar, flour, country and inter-city bus services). However, competition from the de novo private sector and from imports was more important in inhibiting monopoly.
} 
little restructuring would happen anywhere. We have already shown that transition economies have not, in general, suffered from the shortage of 'market-oriented entrepreneurial skills' that Stiglitz attributes to them. The key thing, of course, is the imposition of hard budget constraints (something which Stiglitz himself stresses as important in 1999a). Zero unemployment was maintained under central planning through price controls and generalised excess demand for both labour and goods (in the latter case leading to generalised shortages). Since prices did not reflect relative scarcities under such circumstances, restructuring and privatisation are impossible until prices are liberalised and generalised excess demand is abolished. Furthermore, with a guarantee of full employment and soft budget constraints facing firms, there is nothing to prevent workforces (whether organised in trade unions or not) from demanding ever higher wages ${ }^{32}$. Under such conditions, full employment can only be maintained by an accommodative monetary policy, leading to accelerating (and ultimately hyper-) inflation (Rostowski, 1989). Indeed, inflation can only be stopped by allowing unemployment to reach the natural (or NAIRU) level, and this is certainly not zero! ${ }^{33}$ High inflation makes restructuring and privatisation much harder, because:

1. Rapidly changing nominal prices make it harder to observe the underlying relative prices on which restructuring and privatisation via sales have to be based.

2. Accounting and taxation systems are not inflation adjusted so that the lack of transparency caused by high inflation makes tax avoidance and asset stripping of outside shareholders, stakeholders and the state much easier ${ }^{34}$.

3. In an economy with a large number of remaining price controls, inflation provides huge opportunities for enrichment through arbitrage.

For all these reasons full employment, be it of labour or capital, is simply not an option in transition.

Furthermore, it is striking that in CE hard budget constraints led large SOEs to shed a large amount of labour, to change their product mix etc. This is so-called "defensive restructuring". Grosfeld and Roland (1996) found that a sample of 600 large SOEs in the Czech Republic, Hungary and Poland shed about 30 percent of their workforces in the first 2 years of the transition. This indicates that the dilemma Stiglitz outlines in (1999b, pp.25-26), according to which privatisation is impossible without prior restructuring, but restructuring

\footnotetext{
${ }^{32}$ Strong dictatorships are able, for a time, to resist such pressure by the use of repressive police measures against worker activism, but by simultaneously repressing markets they make restructuring impossible. In any event, many of the dictatorships of the Soviet block were too weak for this by the late 1980s, and the new democracies were quite unable to follow this path. Indeed, even China, which is often cited as a strong dictatorship, abandoned generalised excess demand in the mid-1980s.

${ }^{33}$ Normally, one would expect the actual level of unemployment to need to exceed the 'natural' rate if inflation is to be reduced rather than stabilised. However, if the effect of unemployment on inflation is partly due to its rate of increase (for instance because this influences people's expectation of becoming unemployed in the near future), then early transition economies may stabilise prices with unemployment rates which are not higher than those of many mature market economies, in spite of the far greater number of rigidities in the former (Rostowski, 1998).

${ }^{34}$ At the start of the transition in Russia loans bearing nominal interest rates of 14 percent per annum were considered very expensive by the public, in spite of inflation exceeding 1000 percent per annum. There was thus no objection when the central bank made such loans to preferred individuals, even though the loans were effectively a gift from the state. Also, Variant II of the Russian mass privatisation scheme sold firms to their employees at book value, which - due to the inflation which had occurred since 1991 - meant roughly 10 percent of real value.
} 
by the state was held by the reformers to be impossible, has in fact a very simple solution.

As regards Thesis 17, its validity depends on the country concerned. Those countries that suffered from very high inflation in the pre-transition period and during the early transition $^{35}$, found that this tended to reduce the real value of enterprise debt owed to banks very considerably (thus in early 1990 such debt was the equivalent of about 7 percent of annual GDP in Poland, compared to 70 percent in Czechoslovakia). As a result, debt was not a major factor in the failure of most firms in such countries in the early transition. Far more important was low cash flow due to inefficiency and bad product mix ${ }^{36}$. Furthermore, in those countries that had experienced some marketisation before the fall of communism (Hungary, Poland, Yugoslavia, the USSR), SOE debt was often the result of lobbying of central planners and/or banks by firms. Firms were thus, to a certain degree, responsible for their debt. Stiglitz's point does apply to countries in which strict central planning was maintained until the very end and where inflation was relatively low, but there were only two of these: Czechoslovakia and the German Democratic Republic.

\section{Inequality, Liberalisation and Stabilisation}

It is certainly true, as Stiglitz points out, that the transition to capitalism in the former Soviet block and Yugoslavia has led to a large increase in inequality. This is, perhaps, not entirely surprising to those who have read Marx. However, there is no evidence that, as Stiglitz implies $^{37}$, inequality has increased because reformers adopted "shock therapy". Nor is there evidence that where life expectancy has deteriorated this has occurred because of rapid transition strategies, as is again implied by Stiglitz.

To verify Stiglitz's conclusions we divided the transition countries into "early liberalisers", "late liberalisers" and "non-liberalisers" according to the EBRD classification (EBRD, 1999, p64). We then looked at the changes in Gini coefficients between 1987-89 and 1993-95 reported in Milanovic (1998), and at the change in life expectancy reported by Stiglitz himself in (1999b) following EBRD (1999). It turns out that early liberalisers experienced a much smaller average increase in their Gini coefficients than late liberalisers and non-liberalisers (see Table 3). Similarly, early liberalisers experienced an improvement in life expectancy between 1989 and 1997 (by 0.7 years on average, with no early liberaliser experiencing a decline), while late and non-liberalisers experienced equivalent average declines (although six of the 18 countries in these two categories also experienced an increase in life expectancy). We have a similar story when we look at early stabilisers (although we now have one country, Latvia, where life expectancy fell) $)^{38}$.

\footnotetext{
${ }^{35}$ Poland, Romania, Yugoslavia and the USSR (in Bulgaria SOE debt was denominated in foreign currency and thus could not be inflated away).

${ }^{36}$ This did not prevent debt from accumulating in the worst firms in Poland (Gomulka, 1994), but this was because the good firms paid off their debts when real interest rates became sharply positive at the beginning of the stabilisation programme.

${ }^{37}$ In (1999b, p.2) Stiglitz writes of the lower growth, worse health conditions and greater inequality as great failures of the transition in the Soviet Union and Eastern Europe. Since the rest of the paper is devoted to demonstrating that rapid transition is mistaken, it is natural to assume that it is also, somehow, responsible for these problems.

${ }^{38}$ We define as "early stabilisers" those countries that achieved an inflation rate of under 50 percent per annum (December to December) by 1994, without a subsequent severe relapse. This definition differs from that of EBRD (1999), which is merely that there should have been a stabilisation programme before 1993. We consider this inadequate, as it does not take into account whether the programme was successful, or whether the stabilisation was sustained.
} 
Table 3

Transition, Inequality and Life Expectancy

\begin{tabular}{lcc}
\hline Transition Group & $\begin{array}{c}\text { Change in Gini } \\
\text { Coefficient }\end{array}$ & $\begin{array}{c}\text { Change in Life } \\
\text { Expectancy } \\
\text { (in years) }\end{array}$ \\
\hline Early liberalisers & 4.3 & +0.7 \\
Late liberalisers & 14.0 & -0.8 \\
Non-liberalisers & 11.0 & -0.9 \\
Early stabilisers & 4.9 & +1.0 \\
Late stabilisers & 13.4 & -0.9 \\
Early privatisers (1) & 6.2 & +1.0 \\
Late privatisers (1) & 12.8 & -0.8 \\
Early privatisers (2) & 7.6 & +0.2 \\
Late privatisers (2) & 11.4 & -0.7 \\
\hline
\end{tabular}

Source: own calculations based on EBRD (1999), Milanovic (1998) and Stiglitz (1999b).

Things become less clear when we look at privatisation. On our more restrictive definition of "early privatisation" (a combined score of 7 or 8 in the EBRD (1995) privatisation index ${ }^{39}$ plus over 50 percent of GDP in 1994 generated by the private sector), early privatisers perform far better than late privatisers, both in the deterioration of the Gini coefficient and in life expectancy (only one early-privatiser, Lithuania, has a fall in life expectancy, and that is only 0.3 years). On the other hand if we adopt a looser definition of early privatisation, requiring only that over 50 percent of GNP be generated in the private sector by mid-1994, then the difference between the two groups becomes smaller as regards increases in Gini coefficients, and early privatisers have on average only a tiny increase in life expectancy (also four of the nine countries in the group register declines) ${ }^{40}$. Nevertheless, even in this case, there is no evidence that early privatisers performed worse on inequality and life expectancy than late privatisers! It is worth noting that Russia is not classified as an early liberaliser, as an early stabiliser or as an early privatiser (except on the looser definition).

Turning to Thesis 19, the first thing to note is that Stiglitz's position is quite contradictory. In (1994 and 1999a) he stresses that while both competition and private property are required for a well functioning economy, if a choice has to be made competition is the more important. Yet in (1999b) Stiglitz argues that countries that have liberalised fast have performed worse than those that did so slowly. How then is competition to be achieved without liberalisation? The issue is not addressed directly, but from the texts it seems that, for Stiglitz, competition is mainly to be achieved by "building up the regulatory framework for competition" (1999a, p.19). While such a framework is useful in an economy in which price, trade and entry controls have been abolished, it is not much use on its own. Poland between 1985 and 1989 provides a good example of an economy with a fair degree of demonopolisation in manufacturing, which suffered from severe stagnation as a result of

\footnotetext{
${ }^{39}$ For large and small privatisation (p.10). The maximum score is 8 .

${ }^{40}$ The score of early privatisers deteriorates even more on inequality if we define it only by the achievement of a score of 7 or 8 on the EBRD privatisation index. But this only transfers Kyrgyzstan to the early group, and performance on the average change in life expectancy remains high at +0.8 .
} 
ubiquitous controls.

In (1999b) Stiglitz widens his challenge to include criticism of the "excessive and unwarranted confidence" in the view that early liberalisation and low inflation were, in addition to rapid privatisation, the "cornerstones of a successful transition policy" (his Theses 19 and 20). Stiglitz accepts that, according to economic theory, reducing price distortions through price and trade liberalisation and price stabilisation, in addition to improving incentives through privatisation, "should have moved countries closer to their production possibilities curve". For Stiglitz, the problem arises since "output should have soared instead it plummeted". Much of his challenge to the conventional policy prescription is fired by this apparent contradiction. However, for us this problem does not arise. For, as noted earlier, we associate output falls in the initial phase of transition on the one hand with inherited structural distortions and wage rigidities, and on the other with institutional crises, and therefore see these falls as in most part inevitable. Stiglitz chooses to ignore the fact that, despite wide differences in reform policies, cumulative falls in industrial output, at 40-60 percent, were not just large but also similar between countries. He also ignores that, as Aaslund, Boone and Johnson (1996) first showed, the speed of macroeconomic stabilisation had a significant effect on the time profile of decline, but had little impact upon the magnitude of the cumulative fall of output. Moreover, these falls actually tended to be larger in the countries which were slow in bringing inflation to moderate levels (say below 50 percent per annum) but we agree that the evidence is too weak to suggest the presence of any strong causality from higher inflation to larger cumulative output falls. In any case, apart from increasing inflation, the main effect of a loose macroeconomic policy was to reduce the rate of fall of output and, therefore, to extend the length of the transformational recession. (On this point, see also EBRD's Transition Report 1999, p.64.)

Stiglitz's second point is that in transition, where large relative price changes are required, inflation should not be pushed so low that such changes can only be achieved through nominal falls in some prices (since nominal prices are said to be sticky downwards). Reformers' attempts to eliminate inflation therefore interfered with the dynamic adjustment of the economy and were misguided. Whether Stiglitz is right on the downward stickiness of prices and wages in transition economies or not, he is certainly wrong on what reformers actually did. Rightly or wrongly, with one or two exceptions such as Croatia in 1993 and Bulgaria in 1998, rates of inflation have been reduced relatively gradually, and cumulative price increases since the beginning of the transition have been more than adequate for the necessary relative price changes, registering in the hundreds of percent at the least (with the sole exceptions of the former GDR, the Czech Republic, Hungary and Slovakia).

As regards liberalisation, along with EBRD's Transition Reports, 1995-1999, we interpret the evidence as supporting the proposition that, in the countries which liberalised faster, outputs not only stopped falling earlier, but also started to recover earlier, so that rapid price and trade liberalisation accelerated, but did not magnify, the transformational recession.

\section{Conclusion}

The three central gradualist theses which Stiglitz has put forward have been demonstrated to have either no empirical basis or be contradicted by evidence. Firstly, protecting the existing organisational capital of SOEs, and building the restructuring of the economy on it is not vital for a successful transition - as is shown by the experience of China, CE and the Baltic countries. Secondly, privatising initially to insiders - as actually happened in Russia - need not be an effective mechanism for protecting this organisational capital and enabling successful enterprise restructuring. And thirdly, it is new private enterprise which is vital for 
a successful transition and this new private sector can grow very rapidly during transition, as both the Central European and Chinese cases show.

We also argued that the idea that the new post-Communist economic system should have been built in such a way as to exploit pre-existing (communitarian) social norms rather than copying real existing western capitalist institutions is mistaken, since one of the effects of the total crisis of the old system was that such norms no longer had binding social force (Section 5) ${ }^{41}$. The problem facing governments was anomie, or an absence of the relevant norms. As regards asset stripping, we suggested that the relevant question is: why did it not happen in Russia in such a way as to re-allocate physical capital to new private firms, while it did in some other countries, particularly in the Baltic countries and Poland? We argued that the key point is the extent to which hard budget constraints are imposed on existing SOEs and entry costs are lowered for new firms, which means the extent of price stabilisation and price, entry and trade liberalisation.

What, then, remains of value of Stiglitz's views on economic transition to capitalism? Certainly his recommendation of 'short agency chains' and the criticism of voucher privatisation schemes to outsiders which follows (ie the Czech case, but not the Russian one as he mistakenly asserts). Also, his support for worker management of SOEs and privatisation to workers and managers (with, however, the caveat that, as is shown by the very different Russian and Polish experiences, this will only succeed in those countries where the existing social norms provide support for such institutions). Finally, there must be a minimum legal framework of commercial and property law and law enforcement, without which markets will not develop and market competition will be very limited. However, Stiglitz may have overstated the amount of framework needed because of his tendency to stress regulation and competition enforcement, rather than the protection of property rights and the enabling of competition. Indeed, it seems unlikely that China satisfied Stiglitz's requirement for competition enforcement and regulation of markets in the early years of its transition.

If the Russian transition did not fail for the reasons Stiglitz puts forward, why then did it not succeed until 1999? We suggest it was for the very reasons that the Russian reformers themselves explained - in advance - at the very beginning of the transition. Stiglitz seems unaware that there was a fierce debate in Russia during 1991-92 about the sequencing of the reforms. On the one hand were those who wanted to start with the hardening of budget constraints, and the liberalisation of prices, trade and entry, and disinflation, while on the other were those who argued that SOEs by their very nature could not respond to such changes in the economic environment, and that therefore privatisation had to come first. The Russian reformers and their Western (and Eastern) advisers were in the former camp, the opponents of reform, including the Communist Party of the Russian Federation, in the latter $^{42}$. The 1992 attempt at budget hardening/disinflation cum liberalisation, the Gaidar plan, failed because of opposition in the Supreme Soviet and insufficient support from President Yeltsin ${ }^{43}$. It was this failure which impaired macroeconomic stabilisation and enterprise restructuring, and which led the reformers to switch in the autumn of 1992 to the 'privatisation first' strategy which they had previously opposed.

As had been predicted by the reformers themselves, this meant that enterprises were under less pressure to divest physical assets and labour they did not need, which would have provided the resources needed by de novo private firms to expand. The failure to disinflate and liberalise thoroughly made it hard, both for new firms wishing to set up and old firms

\footnotetext{
${ }^{41}$ The problem of understanding how the capitalist institutions actually work remained.

${ }^{42}$ Because they believed that privatisation would prove either impossible or very slow.

${ }^{43}$ The reasons for his appointment of the inflationist Gennadi Gerashchenko as head of the Central Bank of Russia in June 1992, remain a mystery to this day.
} 
wishing to restructure, to obtain clear information on relative prices. The continued practice of large flows of subsidised credit and entry barriers undermined the credibility of the whole transition strategy. In particular, the Russian reforms failed to convince citizens that Russia is the best place to invest their savings. A large flight of capital has been the result. ${ }^{44}$ The reform strategy adopted also made privatisation for large amounts of cash to foreigners almost impossible and, through the opaqueness it created, enabled the privatisation of central bank seignorage revenue on a massive scale, as well as facilitating criminal types of asset stripping of companies by managers or controlling shareholders (through the lack of transparency high inflation introduced into company accounts). By the time disinflation began to succeed in 1995 many of the destructive processes described by Stiglitz had either been completed, or had at least begun.

Transition happens in time, hence it is likely to be path dependent and, as Stiglitz stresses, sequencing therefore matters. However, the sequencing error which was made in Russia was not so much, as Stiglitz claims, in placing privatisation before the creation of a legal, competitive and regulatory framework for market processes, but rather the much more important error of placing privatisation before liberalisation cum hardening of budget constraints and disinflation. In an environment of near hyperinflation, massively distorted prices and soft budget constraints, the best designed privatisation scheme, occurring in an environment with the requisite legal structure (commercial and company law) and good regulatory and competition frameworks, could not have succeeded in allocating firms to efficient managers who would have successfully restructured them. On the other hand, as the Slovak and Croat experiences show, given free markets, predictable prices, hard budget constraints, and the basics of commercial law, even outrageous degrees of 'crony privatisation' need not lead to the huge disorganisation and social costs experienced in Russia ${ }^{45}$.

This sequencing problem is related to what appears to be the most important difference between Stiglitz and us. In our understanding of the evidence, most Russian SOEs, with their immense inherited problems, were not capable of growth whatever the regulatory framework. Given the financial, managerial and other constraints, and poor positive incentives, they were capable merely of defensive restructuring. In our perspective, the success of transition depends above all on a rapid creation of conditions - institutional, legal, microeconomic and macroeconomic - which are conducive to the development and growth of a new private sector.

The adjustments in policies which Russia adopted in the aftermath of the August 1998 financial crisis are creating the right macroeconomic conditions. With the exception of some authors, notably Kornai (1990), the early conventional view probably over-estimated the positive impact on performance of fast privatisation of SOEs and, by the same token, failed to appreciate sufficiently the key role that a completely new private sector would play in recovery and growth.

\footnotetext{
${ }^{44}$ Russian leaders also wished to keep the pretence of Russia continuing to be a super-power. Consequently, several republics of the fSU received large subsidies during the existence of the rouble zone and military spending has continued at quite a high level.

${ }^{45}$ Russia also had greater problems of industrial structure to overcome. However, Stiglitz does not admit that Russia faced special idiosyncratic difficulties because of its political, military and economic history. Furthermore, both Croatia and Slovakia were involved (like Russia) in the dissolution of the states to which they had belonged. Also, Slovakia's industry (like Russia's) was highly defence dependent, while Croatia was involved in two serious wars, which Russia was not.
} 


\section{References}

Aaslund, A. (1999), “Why has Russia's Economic Transformation been so Arduous?”, World Bank, ABCDE Conference 1999, Washington D.C.

Aaslund, A., Boone, P. and Johnson, S. (1996), "How to Stabilise: Lessons From PostCommunist Countries", Brookings Papers on Economic Activity, 81(1), pp.217-314.

Blanchflower, D. and Oswald, A. (2000), "Measuring Latent Entrepreneurship Across Nations", mimeo, January.

Boone, P. and Horder, J. (1998), "Inflation: Causes, Consequences and Cures”, in Emerging from Communism: Lessons from Russia, China and Eastern Europe, Peter Boone, Stanislaw Gomulka and Richard Layard, (eds.), MIT Press: Cambridge, MA.

Coase, R. H., (1937), “The Nature of the Firm”, Economica, vol.IV, Nov., pp.386-405.

De Broek, M. and Koen, V. (2000), "The 'Soaring Eagle': Anatomy of the Polish Take-Off in the 1990s", IMF Working Paper, WP/00/06, January, Washington D.C.

Dabrowski, M. and Rostowski, J. (1998), "What Went Wrong? The Reasons for the Failure of Stabilisation in Russia in 1992" in Jacek Rostowski (ed.), Macroeconomic Instability in Post-Communist Countries, Clarendon Press: Oxford.

Dabrowski, M. (1999), “Ten Years of the Polish Economic Transition 1989-1999”, paper prepared for the $5^{\text {th }}$ Dubrovnik Conference on Transition Economies: Ten Years of Transition: What Have We Learned and What Lies Ahead, June 23-25, Dubrovnik.

EBRD (1995), Transition Report, European Bank for Reconstruction and Development: London.

EBRD (1999), Transition Report - Ten Years of Transition, European Bank for Reconstruction and Development: London.

Estrin, S. and Wright, M. (1999), "Corporate Governance in the Former Soviet Union: An Overview”, Journal of Comparative Economics, vol.27(3), pp.398-421.

Frydman, R., Pistor, K., Rapaczynski, A. and Turkewitz, J. (1996), "Investing in Insider Dominated Firms: A Study of Russian Voucher Privatisation Funds" in Corporate Governance in Central Europe and Russia, Vol.I, Roman Frydman, Cheryl Gray and Andrzej Rapaczynski, (eds.), Central European University Press: Budapest.

Gomulka, S. (1977), "Slowdown in Soviet Industrial Growth: 1947-75 Reconsidered", European Economic Review, vol.10, pp.37-49.

Gomulka, S. (1986), "Soviet Growth Slowdown: Duality, Maturity and Innovation", American Economic Review, Papers and Proceedings, May 1986.

Gomulka, S. (1988), "The Gerschenkron Phenomenon and Systemic Factors in the Post-1975 Growth Slowdown", European Economic Review, vol.32, pp.451-458. 
Gomulka, S. (1994), "The Financial Situation of Enterprises and its Impact on Fiscal and Monetary Policies, Poland 1992-93”, Economics of Transition, vol.2(2), pp.189-208.

Gomulka, S. (1995), "The IMF-Supported Programs of Poland and Russia, 1990-1994: Principles, Errors and Results", Journal of Comparative Economics, vol.20(3), pp.316-346.

Gomulka, S. (1998a), "The Polish Model of Transformation and Growth", Economics of Transition, vol.6 (1), pp.163-171.

Gomulka, S. (1998b), "Output: Causes of the Decline and the Recovery", in Emerging from Communism: Lessons from Russia, China and Eastern Europe, Peter Boone, Stanislaw Gomulka and Richard Layard, (eds.), MIT Press: Cambridge, MA.

Gray, J. (1995), Enlightenment's Wake, Routledge: London and New York, Chapter 5.

Grosfeld, I. and Roland, G. (1996), "Defensive and Strategic Restructuring in Central European Enterprises", Journal of Transforming Economies and Societies, vol. 3, n. 4, 1996.

International Financial Statistics (1999), International Monetary Fund, Washington D.C.

Kornai, J. (1990), The Road to a Free Economy, Norton \& Company: New York and London.

Lipton, D. and Sachs, J. (1990), "Creating a Market Economy in Eastern Europe: the Case of Poland", Brookings Papers on Economic Activity 1, Brookings Institute: Washington D.C.

McKinnon, R. (1991), The Order of Economic Liberalisation, John Hopkins University Press: Baltimore.

Milanovic, B. (1998), Income, Inequality and Poverty during the Transition from Planned to Market Economy, World Bank: Washington D.C.

Rostowski, J. (1989), "Market Socialism is not Enough: Inflation vs. Unemployment in Reforming Communist Economies”, Communist Economies, vol.I, no.3, Oxford.

Rostowski, J. (1993), "Private Sector Development, Structural Change and Macroeconomic Stabilization: the Case of Poland 1988-93", Discussion Paper No. 159, Centre for Economic Performance, London School of Economics.

Rostowski, J. (1998), Macroeconomic Instability in Post-Communist Countries, Introduction to Part I, Jacek Rostowski, Clarendon Press: Oxford.

Schaffer, M., Bevan, A. and Mochrie, R. (1998), "Bank and Enterprise Restructuring in Transition Economies", UN, Economic Commission for Europe, Economic Survey of Europe. No.3.

Stiglitz, J. (1994), “Whither Socialism?”, MIT Press: Cambridge, MA. 
Stiglitz, J. (1999a), “Whither Reform?”, Annual Bank Conference on DevelopmentEconomics, April, Washington D.C.

Stiglitz, J. (1999b), “Quis Custodiet Ipsos Custodies?”, Annual Bank Conference on Development Economics - Europe, June, World Bank, Paris.

Wiles, P. (1977), Economic Institutions Compared, p.608, Blackwell: Oxford.

Woo, W.T. (1998), "Why China Grew", in Emerging from Communism: Lessons from Russia, China and Eastern Europe, Peter Boone, Stanislaw Gomulka and Richard Layard, (eds.), MIT Press: Cambridge, MA.

Xu, C. and Zhuang, J. (1999), "Why China Grew: The Role of Decentralization" in Emerging from Communism: Lessons from Russia, China and Eastern Europe, Peter Boone, Stanislaw Gomulka and Richard Layard, (eds.), MIT Press: Cambridge, MA.

Yasin, Y. G. (1999), "Defeat or Retreat? Russia's Reforms and the Financial Crisis”, mimeo, Moscow. 


\section{CENTRE FOR ECONOMIC PERFORMANCE Recent Discussion Papers}

470 B. Petrongolo C. A. Pissarides

469 W. H. Buiter

468 A. S. Litwin

467 P. B. Kenen

466 S. Gomulka

J. Lane

465 F. Green

S. McIntosh

464 J. P. Neary

463 M. Güell

462 W. H. Buiter

461 M. Güell

460 P. Ramezzana

459 H. Lehmann J. Wadsworth

$458 \quad$ R. Griffith

S. Redding

J. Van Reenen

457 J. Swaffield

456 C. Dougherty
Looking Into the Black Box: A Survey of the Matching Function

Monetary Misconceptions

Trade Unions and Industrial Injury in Great Britain

Currency Areas, Policy Domains and the

Institutionalization of Fixed Exchange Rates

A Simple Model of the Transformational Recession Under a Limited Mobility Constraint

Working on the Chain Gang? An Examination of Rising Effort Levels in Europe in the 1990s

R\&D in Developing Countries: What Should Governments Do?

Employment Protection and Unemployment in an Efficiency Wage Model

Optimal Currency Areas: Why Does the Exchange Rate Regime Matter?

Fixed-Term Contracts and Unemployment: An Efficiency Wage Analysis

Per Capita Income, Demand for Variety, and International Trade: Linder Reconsidered

Tenures that Shook the World: Worker Turnover in Russia, Poland and Britain

Mapping the Two Faces of R\&D: Productivity Growth in a Panel of OECD Industries

Gender, Motivation, Experience and Wages

Impact of Work Experience and Training in the Current and Previous Occupations on Earnings: Micro Evidence from the National Longitudinal Survey of Youth

Union Decline in Britain 
453 H. Gospel

G. Lockwood

P. Willman

452

D. Metcalf

K. Hansen

A. Charlwood

P. Martin

H. Rey

450 P. Martin

H. Rey

449

448
A. Manning
Labour Supply, Search and Taxes

S. Nickell

L. Nunziata

447 W. Buiter

446 R. Portes

H. Rey

445 G. Duranton

D. Puga

444 D. Quah

443 L. Feinstein

442 D. Quah

441

440 E. Mellander

439 F. Green

A. Felstead

D. Gallie
The Right to Know: Disclosure of Information for

Collective Bargaining and Joint Consultation

Unions and the Sword of Justice: Unions and Pay Systems, Pay Inequality, Pay Discrimination and Low Pay

Financial Integration and Asset Returns

Financial Super-Markets: Size Matters for Asset Trade

Employment Patterns in OECD Countries

The Fallacy of the Fiscal Theory of the Price Level

The Determinants of Cross-Border Equity Flows

Nursery Cities: Urban Diversity, Process Innovation and the Life-Cycle of Products

UK Phillips Curves and Monetary Policy

The Relative Economic Importance of Academic, Psychological and Behavioural Attributes Developed in Childhood

Cross-Country Growth Comparison: Theory to Empirics

Internet Cluster Emergence

The Multi-Dimensional Nature of Labour Demand and Skill-Biased Technical Change

Computers are Even More Important than You Thought:

An Analysis of the Changing Skill-Intensity of Jobs 